\title{
DISCOVERY AND TESTIMONY OF UNRETAINED EXPERTS: CREATING A CLEAR AND EQUITABLE STANDARD TO GOVERN COMPLIANCE WITH SUBPOENAS
}

A litigant's attempt to discover information or compel testimony from an unwilling nonparty expert would at one time have been an extraordinary event. ${ }^{1}$ In recent years, however, litigants have increasingly sought to subpoena unretained experts. ${ }^{2}$ Some knowledgeable observers fear this trend will continue as litigation becomes more complex and expert opinion increasingly important. ${ }^{3}$ The cases involving compelled expert testiniony or discovery ${ }^{4}$ raise two issues: Slould a nonparty expert

1. See, e.g., Graham, Discovery of Experts Under Rule 26(b)(4) of the Federal Rules of Civil Procedure: Part One, An Analytical STudy, 1976 U. ILL. L.F. 895, 936.

2. This note deals primarily with the treatment of a subciass of witnesses-experts who have not been retained by the party seeking information and who have no role in the underlying events being litigated. Although the term "expert" is inexact, the distinguishing characteristic of an expert witness is some kind of specialized skill and knowledge. See FED. R. EviD. 702 (defining an expert witness as a person with special "knowledge, skill, experience, training, or education" sufficient to qualify him as an expert on the subject to which his testimony relates). Professors Wright and Miller have classified experts into four categories: (1) experts retained or specially employed to testify at trial; (2) experts retained or employed to help prepare for trial but not to testify; (3) experts informally consulted in preparation for trial but not retained; and (4) experts whose information is not acquired in preparation for trial. 8 C. Wriger \& A. Miller, Federal Practice and ProceDURE § 2029, at 250 (1970). Professor Graham has suggested the term "occurrence witness" to describe experts who were actors in or contemporaneous viewers of events forming the basis of a given lawsuit. Graham, supra note 1, at 941. Professor Maurer has extended this terminology and has used the term "nonoccurrence wilness" to describe those experts, retained or unretained, who have not viewed or taken part in the events underlying the lawsuit. Maurer, Compelling the Expert Witness: Faimess and Utility Under the Federal Rules of Civil Procedure, 19 GA. L. REv. 71, 83 (1984).

3. As one judge has stated: "With all the public funding presently available, in addition to the private funds available to private litigants, and consequent expansion of litigation, unwilling experts on school discrimination, environment and psychiatry, for example, as well as surgeons, could be made subject to intermittent call." Kaufman v. Edelstein, 539 F.2d 811, 823 (2d Cir. 1976) (Gurfein, J., concurring).

4. See, e.g., Farnsworth v. Procter \& Gamble Co., 758 F.2d 1545, 1546-47 (11th Cir. 1985) (defendant in product liability suit sought study on toxic shock syndrome); Deitchman v. E.R. Squibb \& Sons, Inc., 740 F.2d 556, 558 (7th Cir. 1984) (manufacturer sought study on female genital cancers froin university registry); Buchanan v. American Motors Corp., 697 F.2d 151, 152 (6th Cir. 1983) (defendant sought data reports, lab notes, and other material related to safety defects in jeep); 
be compelled to comply with a subpoena? If so, what level of compensation is appropriate?

The present approach in this area is problematic in several respects. Under existing rules, unretained experts can be forced to provide opinions or the results of research, even though a hitigant may be able to obtain the information from another source. ${ }^{5}$ Such disclosure could jeopardize the expert's ability to continue working in a given field. ${ }^{6}$ Furthermore, the unretained expert is often inadequately compensated for the specialized information.?

The expert's situation is rendered more difficuit by the fact that in most jurisdictions a nonparty cannot appeal a discovery order in a civil suit without first being held in contempt of court. ${ }^{8}$ Thus, an unretained

EEOC v. University of Notre Dame Du Lac, 715 F.2d 331, 338 (7th Cir. 1983) (party sought academic research); In re Petroleum Prods. Antitrust Litig, 680 F.2d 5, 7 (2d Cir.) (party sought disclosure of sources of information contained in expert's newsletter), cert. denied, 459 U.S. 909 (1982); Dow Chem. Co. v. Allen, 672 F.2d 1262, 1266 (7th Cir. 1982) (party sought studies and records related to animal toxicity studies); Kaufmon, 539 F.2d at 812 (government subpoenaed two computer experts in connection with antitrust litigation); Carter-Wallace, Inc. v. Otte, 474 F.2d 529, 536 (2d Cir. 1972) (party subpoenaed nonparty expert who had testified on related matter at prior trial), cert. denied, 412 U.S. 929 (1973); In re J.A. Frates, No. M8-85 (S.D.N.Y. Sept. 25, 1985) (available on Lexis, Genfed library, Dist file) (party sought nonparty's business securities report for information on specific company's stock); In re "Agent Orange" Prod. Liab. Litig., 105 F.R.D. 577, 580-83 (E.D.N.Y. 1985) (litigants sought to compel unretained and retained experts to testify and provide discovery information in class action); Cantaline v. Raymark Indus., Inc., 103 F.R.D. 447, 450-52 (S.D. Fla. 1984) (party sought architectural blueprimts and other information from nonparty in asbestos product liability suit); Lampshire v. Proctor \& Gamble Co., 94 F.R.D. 58, 60 (N.D. Ga. 1982) (tanpon manufacturer sought personal information about participants in toxic shock syndrome study conducted by Center for Disease Control); Wright v. Jeep Corp., 547 F. Supp. 871, 872 73 (E.D. Mich. 1982) (manufacturer subpoenaed underlying research for study in product hability suit); Fitzpatrick v. Holiday Inns, Inc., 507 F. Supp. 979, 980 (E.D. Pa. 1981) (nonparty physician subpoenaed); Grumman Aerospace Corp. v. Titarium Metals Corp. of Am., 91 F.R.D. 84, 87-88 (E.D.N.Y. 1981) (plaintiff in antitrust suit sought economic report prepared by independent experts for Department of Defense); In re New York City Mun. Sec. Litig., 30 Fed. R. Serv. 2d 842, 843 (S.D.N.Y. 1980) (party sought to compel nonparty expert to provide documents that would divulge trade secrets); City of Groton v. Connecticut Light \& Power Co., 84 F.R.D. 420, 422-23 (D. Conn. 1979) (nonsettling plaimtiff sought to force production of terms of settlement between coplaintiff and defendant); Richards of Rockford, Inc. v. Pacific Gas \& Elec. Co., 71 F.R.D. 388, 389-90 (N.D. Cal. 1976) (party sought research information from nonparty professor in breach of contract and defamation action); Apicella v. McNeil Laboratories, Inc., 66 F.R.D. 78, 80-81 (E.D.N.Y. 1975) (party sought documents and correspondence from authors of medical newsletter); Karp v. Cooley, 349 F. Supp. 827, 836 (S.D. Tex. 1972) (physician subpoenaed in medical malpractice case), aff'd, 493 F.2d 408 (5th Cir.), cert. denied, 419 U.S. 845 (1974).

5. See FED. R. Civ. P. 26, 45.

6. See infra notes $85-92$ and accompanying text.

7. See infra note 22 and accompanying text.

8. See, eg., United States v. Ryan, 402 U.S. 530, 532-33 (1971) (nonparty who has not been held in contempt cannot appeal subpoena except when denial of immediate review "would render impossible any review whatsoever"); DeMasi v. Weiss, 669 F.2d 114, 122 (3d Cir. 1982) ("A nonparty witness may not obtain appellate review of the mere issuance of a discovery order requiring production of information or other action."); Kaufman v. Edelstein, 539 F.2d 811, 814 (2d Cir. 
expert usually must either comply with the subpoena or face contempt sanctions and then appeal. Moreover, the language in some decisions casts doubt on a nonparty's right to object to the subpoena.9

The ABA House of Delegates passed a resolution in $1985^{10}$ recommending that Rule $45^{11}$ of the Federal Rules of Civil Procedure be amended to deal with this problem. The proposed amendment would give standing to nonparties to object to the issuance of subpoenas and would ensure that "a nonparty expert witness ... not be required to give opinion testimony without compensation."12

This note also advocates changing the Federal Rules to require greater solicitude for the interests of persons compelled to provide information in disputes in which they have no stake. The note suggests, however, that the ABA's proposed amendment does not go far enough. Specifically, the amendment should also provide that litigants may coinpel discovery or testimony from unretained experts only in certain limited circumstances.

The note begins by discussing how the present rules treat the coinpeting interests of litigants and nonparty experts who do not want to participate in hitigation. ${ }^{13}$ It demonstrates that the Federal Rules give insufficient weight to the equitable considerations associated with objections to subpoenas directed at nonparty experts. ${ }^{14}$ It then explains how existing remedies are inadequate. ${ }^{15}$ After discussing alternative reform proposals, ${ }^{16}$ the note concludes by recommending that Rule 45 be amended to extend to nonparty experts protection similar to that enjoyed by attorneys under the work-produce doctrine. ${ }^{17}$ The proposed amendment offers a clear standard for weighing the competing policies of protecting nonparty experts from unnecessary intrusions and providing a

1976) ("The remedy of the party wishing to appeal is to refuse to answer and subject himself to criminal contempt; that of the non-party witness is to refuse to answer and subject himself to civil or criminal contempt."). But see Cates v. LTV Aerospace Corp., 480 F.2d 620, 622 (5th Cir. 1973) (discovery orders may be appealed in certain instances involving executive privileges); Covey Oil $\mathrm{Co}$. v. Continental Oil Co., 340 F.2d 993, 996-97 (10th Cir.) (motion by nonparty to quash subpoena was appealable due to need to protect possible disclosure of trade secret), cert denied, 380 U.S. 964 (1965).

9. Report to the House of Delegates, 1985 A.B.A. SEc. LITIG. 8-9.

10. American Bar Association House of Delegates, Formal Resolution (1985) [hereinafter House OF DELEGATES FoRMAL RESOLUTTON].

11. Rule 45, which grants the court power to impose contempt sanctions, covers subpoenas ad testificandum and subpoenas duces tecum.

12. HOUSE OF DELEGATES Formal Resolution, supra note 10.

13. See infra notes $18-41$ and accompanying text.

14. See infra notes $42-66$ and accompanying text.

15. See infra notes $67-82$ and accompanying text.

16. See infra notes $83-99$ and accompanying text.

17. See infra notes 100.08 and accompanying text. 
means for compelling the disclosure of important information possessed by nonparties.

\section{Problems Created by Liberal Discovery and Relevancy REQUIREMENTS UNDER THE FEDERAL RULES OF CIVIL Procedure}

Although unretained experts ostensibly have the same duties as other citizens to provide information that could be useful in resolving a dispute, ${ }^{18}$ such experts also have a particularly strong interest in privacy. Subpoenas have been challenged on the grounds that disclosure might limit the expert's ability to conduct research, ${ }^{19}$ cause the expert to be at a competitive disadvantage, ${ }^{20}$ or place the unwilling expert in an uncomfortable or controversial position. ${ }^{21}$ In addition, the minimum compensation required under the Federal Rules is insignificant compared to the potential personal and professional costs of providing the information. ${ }^{22}$

The burden imposed on the expert witness differs from that imposed on the nonexpert witness. The nonexpert witness has observed or participated in events leading to the litigation; the subpoenaed expert, in contrast, is being compelled to give opinion testimony or provide information that is the product of professional efforts. ${ }^{23}$ The expert also is in a different position because his information, unlike that of a person who actually observed or participated in the events at issue, often can be supplied by someone else.

18. See, eg., United States v. Bryan, 339 U.S. 323, 331 (1950) ("[P]ersons summoned as witnesses by competent authority have certain minimum duties and obligations which are necessary concessions to the public interest in the orderly operation of legislative and judicial machinery."); Blackmer v. United States, 284 U.S. 421,438 (1932) ("[O]ne of the duties which the citizen owes to his government is to support the administration of justice by attending its courts and giving his testimony whenever he is properly summoned.").

19. See, eg., Farnsworth v. Proctor \& Gamble Co., 758 F.2d 1545, 1547 (11th Cir. 1985); Deitchman v. E.R. Squibb \& Sons, 740 F.2d 556, 559 (7th Cir. 1984); Dow Chem. Co. v. Allen, 672 F.2d 1262, 1269 (7th Cir. 1982).

20. See, eg., In re J.A. Frates, No. M8-85 (S.D.N.Y. Sept. 25, 1985) (available on Lexis, Genfed library, Dist file); In re Subpoenas Duces Tecum to Lelman Bros. Kuhn Loeb, Inc., No. M8-85 (S.D.N.Y. Nov. 14, 1983) (available on Lexis, Genfed library, Dist file); In re New York City Mun. Sec. Litig., 30 Fed. R. Serv. 2d 842, 842-43 (S.D.N.Y. 1980).

21. Karp v. Cooley, 349 F. Supp. 827, 836 (S.D. Tex, 1972), aff'd, 493 F.2d 408 (5th Cir.), cert. denied, 419 U.S. 845 (1974).

22. The Federal Rules require that a litigant tender to a witness subpoenaed for a deposition "the fees for one day's attendance and the mileage allowed by law." FED. R. Civ. P. 45(c). The witness fee is set at \$30 per day. See 28 U.S.C. § 1821(b) (1982).

23. As one court pointed out, "[t]lhe expert not only suffers a loss of time froin his or her job, like an ordinary witness; he or she also suffers a loss in divulging dearly won expertise." In re "Agent Orange" Prod. Liab. Litig., 105 F.R.D. 577, 582 (E.D.N.Y. 1985). 
Federal courts may use Rule 26 and Rule 45 to limit the information obtainable from a nonparty or to construct protective measures to reduce the burden imposed by a subpoena. ${ }^{24}$ Both rules allow courts significant discretion when deciding whether to quash or restrict subpoenas, though neither requires that courts consider a nonparty's expertise or interest in the material sought. Furthermore, neither rule mandates that the litigant pay the unretained expert fair compensation for the information provided.

Rule 45 enables a court to weigh, to a limited extent, the interests of nonparties from whom evidence is sought. For example, Rule 45(b)(1) permits a court to modify or quash unreasonable or oppressive subpoenas. ${ }^{25}$ If the subpoenaed nonparty submits a timely objection to the court, compliance is not required until the court rules on the motion. ${ }^{26}$ Furthermore, Rule 45(b)(2) allows a court to quash a subpoena if the requesting party fails to advance the reasonable costs of producing the docuinents. ${ }^{27}$

Rule 26 sets the general standards for discovery. Parties can discover "any matter, not privileged, which is relevant to the subject matter" of a pending action. ${ }^{28}$ The information sought need not be admissible at trial as long as it "appears reasonably calculated to lead to the discovery of admissible evidence."29 Rule 26 grants litigants liberal discovery of documentary and other information, 30 including discovery aimed at nonparty witnesses through the subpoena process. Liberal discovery, however, is tempered in some respects: the work product of lawyers is protected and the discovery of information possessed by retained experts is subject to certain restraints. ${ }^{31}$ Yet neither the unretained ex-

24. See infra notes 25-27, 32-41.

25. FED. R. Civ. P. $45(b)(1)$.

26. $I d .45(b)$.

27. $I d .45(b)(2)$.

28. $I d .26(b)(1)$.

29. $I d$.

30. The rule states in part that a party may obtain discovery regarding the "existence, description, nature, custody, condition and location of any books, documents, or other tangible things and the identity and location of persons having knowledge of any discoverable matter." Id. See C. Wright, The LaW oF Federal CourTs § 81, at 543 (4th ed. 1983) ("The scope of discovery contemplated by Rule 26 is extremely broad.').

31. Rule 26(b)(4) contains two standards: one for discovery from retained experts who are expected to testify and one for discovery from retained experts who are not expected to testify. See FED. R. Civ. P. 26(b)(4). The rule, arnended in 1970 to provide this protection for retained witnesses, "reject[s] as ill-considered the decisions which have sought to bring expert information within the work-product doctrine" and "adopt[s] a form of the inore recently developed doctrine of 'unfaimess.' "' See FED. R. Crv. P. 26(b)(4) advisory committee's note (citing United States v. McKay, 372 F.2d 174, 176-77 (5th Cir. 1967), and United States v. 23.76 Acres of Land, 32 F.R.D. 593, 597 (D. Md. 1963)). 
pert's expertise nor his nonparty status imposes limits on the broad applicability of Rule 26.

Recent amendments to Rule 26 do temper liberal discovery somewhat by giving courts authority to limit discovery on practical or equitable grounds when a party abuses the process. ${ }^{32}$ Under the amended rule, a judge may limit requests that are unreasonably burdensome, expensive, cumulative, or duplicative. ${ }^{33}$ As a check, the amended rule requires attorneys to certify that discovery requests are made in good faith. ${ }^{34}$ It also authorizes courts to impose sanctions for abuse of discovery. ${ }^{35}$

Moreover, Rule 26(c) allows a person to seek a protective order when a discovery request is oppressive, unduly burdensome, or would result in unnecessary expense. ${ }^{36}$ The rule, designed as a safeguard agamst abuses of the almost unlimited riglıt of discovery under Rule 26, lists eight types of protective orders ${ }^{37}$ and allows courts to establish additional protections as justice requires. Persons seeking protective orders must show good cause, ${ }^{38}$ but courts have failed to develop a single standard for testing good cause. Some weigl the burden on the subpoenaed party agaimst the interests of the litigant, ${ }^{39}$ while others require more than a weighing of relative hardships. ${ }^{40}$ In any event, the protective or-

\footnotetext{
32. See FED. R. Civ. P. 26(b)(1).

33. Id.

34. Id. $26(\mathrm{~g})(1)$.

35. Id. $26(\mathrm{~g})$.

36. Id. $26(\mathrm{c})$.

37. An order may provide:

(1) that the discovery not be had;

(2) that the discovery may be had only on specific terms and conditions, including a

designation of the time or place;

(3) that the discovery may be had only by a method of discovery other than that selected by the party seeking discovery;

(4) that certain matters not be inquired into, or that the scope of the discovery be limited to certain matters;

(5) that discovery be conducted with no one present except persons designated by the court;

(6) that a deposition after being sealed be opened only by order of the court;

(7) that a trade secret or other confidential research development or commercial informa-

tion not be disclosed or be disclosed only in a designed way; and

(8) that the parties simultaneously file specified documents or information enclosed in

sealed envelopes to be opened as directed by the court.
} Id.

38. $I d$.

39. See, eg., Farnsworth v. Proctor \& Gamble Co., 758 F.2d 1545, 1547 (11th Cir. 1985); Deitchunan v. E.R. Squibb \& Sons, 740 F.2d 556, 559 (7th Cir. 1984); Apicella v. McNeal Laboratories, 66 F.R.D. 78, 82 (E.D.N.Y. 1975).

40. See, e.g., General Dynamies Corp. v. Selb Mfg. Co., 481 F.2d 1204, 1212 (8th Cir.), cert. denied, 414 U.S. 1162 (1973). Good cause often requires a showing of specific and identifiable harm, such as the likelinood of serious injury. See, eg., Zenith Radio Corp. v. Matsushita Elec. Indus. Co., 529 F. Supp. 866, 891 (E.D. Pa. 1981). A showing that disclosure will cause "a clearly defined and very serious injury" has also been required in at least one case. United States v. International Business Machs. Corp., 67 F.R.D. 40, 46 (S.D.N.Y. 1975). 
der must be narrowly drawn, ${ }^{41}$ and the nonparty expert who seeks a protective order will incur legal expenses in doing so.

In short, Rule 26 provides insufficient protection for the unretained expert. Furthermore, the rule creates a double standard by protecting the work of retained experts without extending similar protection to the work of unretained experts.

\section{The Chaotic Judicial Attempt to Define Protections FOR NONPARTY EXPERTS}

Courts have disagreed sharply over how to treat nonparty experts. Even the fundamental question of whether the nonparty expert has an intellectual property right in his information remains unresolved. One judge, for example, has pointed out that an expert's knowledge is his "stock in trade." 42 So viewed, compulsion to supply such information to litigants may amount to a taking of property. Other judges have viewed privileges and relevancy requirements as the only restraints on discovery of information possessed by unretained experts. ${ }^{43}$ But the relevancy requirement erects only a minor hurdle for litigants demanding such information, ${ }^{44}$ and courts generally do not recognize a privilege for experts. ${ }^{45}$

In apparent acknowledgment of the unfairness of compelling experts to comply with discovery or testimomial subpoenas, a host of tests have been employed to provide nonparties, particularly nonparty experts, with added protection. In Kaufman v. Edelstein, for example, Judge Friendly presented a list of factors designed to assist trial courts in deciding whether to compel expert testimony. ${ }^{46}$ In his view, trial courts should consider the following:

the degree to which the expert is being called because of his knowledge of facts relevant to the case rather than in order to give opinion testimony; the difference between testifying to a previously formed or expressed opinion and forming a new one; the possibility that, for other reasons, the witness is a unique expert; the extent to which the calling

41. See, eg., In re Halkin, 598 F.2d 176, 191 (D.C. Cir. 1979).

42. In re "Agent Orange" Prod. Liab. Litig,, 105 F.R.D. 577, 582 (E.D.N.Y. 1985). See also In re Subpoenas Duces Tecum to Lehman Bros. Kuhn Loeb, Inc., No. M8-85 (S.D.N.Y. Nov. 14, 1983) (available on Lexis, Genfed library, Dist file).

43. See, e.g., United States v. International Business Machs. Corp., 83 F.R.D. 97, 105-06 (S.D.N.Y. 1979). Information is considered relevant if it is "reasonably calculated to lead to the discovery of admissible evidence" FED. R. Crv. P. 26(b)(1).

44. See C. WRIGHT, supra note 30 , § 81, at 548-49.

45. See Kaufman v. Edelstein, 539 F.2d 811, 820 (2d Cir. 1976). The court pointed out that it perceived "no sufficient basis in principle or precedent for holding that the common law recognizes any general privilege to withhold ... expert knowledge." Id. But see infra note 94 and accompanying text.

46. Kaufman, 539 F.2d at 822 . 
party is able to show the unlikelihood that any comparable witness will willingly testify; the degree to which the witness is able to show that he has been oppressed by having continually to testify. 47

Judge Friendly proposed this solution as the "utmost" courts could do in the absence of a privilege, statute, or controlling rule. ${ }^{48}$ However, he did not indicate precisely how the factors were to be applied; not surprisingly, no clear standard has einerged.

Two cases involving the same expert on jeep crash studies illustrate this lack of consensus. In one case, Buchanan v. American Motors Corp., 49 an autoinobile manufacturer defending against a wrongful death suit attempted to discover from an expert the research used to prepare a study on vehicle safety. ${ }^{50}$ The district court found the subpoena unreasonably burdensome, and the United States Court of Appeals for the Sixth Circuit affirmed, reasoning that authority to quash based on the expert's nonparty status rested within the discretion of the trial court. ${ }^{51}$

In an earier case also arising in the Sixth Circuit, Wright v. Jeep Corp., 52 the district court rejected an attempt by the same expert to invoke a privilege for academic research. ${ }^{53}$ The court required the expert to comply with a subpoena almost identical to the one quashed in Buchanan, ${ }^{54}$ holding that the burden imposed was no different from that placed on any person who acquires knowledge relevant to an issue in contention. ${ }^{55}$ The court then invoked its power under Rule $45(\mathrm{~b})$ to require the defendant to pay the expert a reasonable fee, costs, and a portion of expenses for his research. 56

These contrary holdings involving the same expert and information sought for identical purposes illustrate the substantial potential for capriciousness in the application of protections afforded unretained nonparty experts. The courts have not shown a willingness to develop a uniform standard. Some courts considering motions to quash have given weight

47. Id.

48. Id.

49. 697 F.2d 151 (6th Cir. 1983).

50. Id. at 151. The automobile manufacturer sought discovery from the expert because it anticipated that the plaintiff would "use the research study as one basis for expressing an adverse expert opinion about the safety" of its jeeps. Id. at 152.

51. Id. The coust also noted that compliance with the subpoena "would require the expert who has no direct connection with the hitigation to spend many days testifying and disclosing all of the raw data, including thousands of docuunents, accumulated over the course of a long and detailed research study." Id.

52. 547 F. Supp. 871 (E.D. Mich. 1982).

53. Id. at 875. The court also rejected the expert's claim that his status as an unretained expert gave him a right to refuse to testify. Id. at 874 .

54. $I d$. at 877.

55. Id. at 876 .

56. Id. at 877 . 
to the nonparty status of the person subpoenaed.57 Other courts have required the party seeking information from the nonparty to guaranty reasonable compensation ${ }^{58}$ or show a substantial need for the information.59 Still other courts have held that certain experts have a qualified privilege as researchers or have first amendment rights relating to academic freedom. 60

Additionally, various state courts have developed a host of criteria for deciding whether or when an unretained expert must comply with a subpoena in a civil action. ${ }^{61}$ And it is probably not possible to identify all the approaches actually used by federal judges because reported discovery decisions often follow appeals of unreported magistrates' orders.

In sum, no uniform court standard defines when a nonparty expert

57. See, e.g., Buchanan v. American Motors Corp., 697 F.2d 151, 152 (6th Cir. 1983). But see Cantaline v. Raymark Indus., 103 F.R.D. 447, 452 (S.D. Fla. 1984) (party and nonparty alike owe duty of obedience to court).

58. See, eg. United States v. Columbia Broadcasting Sys., 666 F.2d 364, 371-72 (9th Cir. 1982) (litigant can be ordered to reimburse nonparty for discovery costs); In re "Agent Orange" Prod. Liab. Litig., 105 F.R.D. 577, 581-82 (E.D.N.Y. 1985) (expert's entitlement to a reasonable fee arises under common law precedent and the court's authority under FED. R. CIV. P. 1); Wright v. Jeep Corp., 547 F. Supp. 871,877 (E.D. Mich. 1982) (defendant not seeking benefits of nonparty's information must advance reasonable fee).

59. See, e.g., Deitchman v. E.R. Squibb \& Sons, 740 F.2d 556, 565 (7th Cir. 1984); EEOC v. University of Notre Dame Du Lac, 715 F.2d 331, 338 (7th Cir. 1983); Dow Chem. Co. v. Allen, 672 F.2d 1262, 1272-73 (7th Cir. 1982); Centurion Indus., Inc. v. Steurer \& Assocs., 665 F.2d 323, 326 (10th Cir. 1981); Carter-Wallace, Inc. v. Otte, 474 F.2d 529, 536-37 (2d Cir. 1972), cert. denied, 412 U.S. 929 (1973); New York State Energy Research and Dev. Auth. v. Nuclear Fuel Servs., Inc., 36 Fed. R. Serv. 2d 1511, 1519 (W.D.N.Y. 1983); City of Groton v. Connecticut Light \& Power Co., 84 F.R.D. 420, 422 (D. Conn. 1979). But see Grinnell Corp. v. Hackett, 70 F.R.D. 326, 333 (D.R.I. 1976) (only relevancy and necessity need be shown); Cooney v. Sun Shipbuilding \& Drydock Co., 288 F. Supp. 708, 717 (E.D. Pa. 1968) (same).

60. See, eg., Deitchman v. E.R. Squibb \& Sons, 740 F.2d 556, 560-65 (7th Cir. 1984) (recognizing the possibility of a qualified privilege for researchers); Dow Chem. Co. v. Allen, 672 F.2d 1262, 1276-77 (7th Cir. 1982) ("For present purposes, our point is simply that . . . interest in academic freedom nay properly figure into the legal calculation of whether forced disclosure would be reasonable."); Lampshire v. Proctor \& Gamble Co., 94 F.R.D. 58, 60 (N.D. Ga. 1982) (acknowledging that public health research often involves confidential information that should be protected from disclosure); Richards of Rockford, Inc. v. Pacific Gas \& Elec. Co., 71 F.R.D. 388, 390 (N.D. Cal. 1976) ("Compelled disclosure of confidential information would without question severely stifie research into questions of public policy ... ."); Apicella v. McNeil Laboratories, Inc., 66 F.R.D. 78, 84-85 (E.D.N.Y. 1975) (denying discovery of unpublished, underlying research for article published in inedical newsletter because of need to protect confidential sources). But see In re Dinnan, 661 F.2d 426,427 (5th Cir. Unit B Nov. 1981) (refusing to recognize "academic freedon"" privilege for university professor subpoenaed to provide information regarding vote on promotion of colleague); Grumman Aerospace Corp. v. Titantium Metals Corp., 91 F.R.D. 84, 87 (E.D.N.Y. 1981) (fact that consulting firm entered into confidentiality agreements would not prevent compulsion of information prepared by that firm).

61. See, e.g., Mason v. Robinson, 340 N.W.2d 236, 242 (Iowa 1983) (substantial necessity nust be shown); Fenlon v. Thayer, 127 N.H. 702, 707, 506 A.2d 319, 322 (1986) (rule favoring testimonial coinpulsion should apply to all experss); see also infra note 94. 
will be required to submit to a subpoena.62 Inconsistent decisions are disturbing because they frustrate one of the purposes of having rules of procedure. Procedural systems should treat like cases alike. ${ }^{63}$

The problem of inconsistency in applying the federal rules to expert witnesses is not new. A similar problein existed not long ago with respect to retained expert witnesses. Before 1970, the federal courts applied a number of different tests to determine whether coinpulsion would be proper. ${ }^{64}$ One contemporary commentator observed that "no sound body of coherently related propositional law is deducible froin the cases, nor have general standards employed by various courts yet furnished an adequate method of attack in this "hazy frontier of the discovery process." "65 Rulemakers addressed this absence of a uniform standard by revising Rule $26(\mathrm{~b})(4)$ to restrict discovery of information possessed by retained experts. ${ }^{66}$

\section{Controlling the Subpoena Process}

Some may argue that the nonparty expert witness has at least two potential remedies against the litigant who abuses the subpoena process. First, the nonparty expert might bring an abuse of process action against the subpoenaing party. Second, he might seek sanctions under Rule 11. As explained below, however, neither of these remedies is adequate.

\section{A. Abuse of Process Actions.}

Tort relief for abuse of process might be seen as one way to deter some abusive subpoenas. ${ }^{67}$ One may bring an abuse of process action

62. See, e.g., Stein, Oral Depositions in Federal Civil Practice, in Practicing Law InstituTe, Depositions, Expert WITNEsses, aNd Demonstrattve Evidence IN Personal INJURy CASES 9, 38 (1985); Coininent, Compelling Experts to Testify: A Proposal, 44 U. CHI. L. REV. 851 , 851 (1977). Some recent cases on the matter are collected in Annotation, Rights of Independent Expert to Refuse to Testify as to Expert Opinion, 50 A.I.R. 4th 680 (1986).

63. See Resnik, Precluding Appeals, 70 CORNELL L. REv. 603, 611 (1985) ("[C]onsistency is the systematic analogue of the impartiality feature demanded of individual decisionunakers.").

64. See FED. R. Crv. P. 26(b)(4) advisory committee's note.

65. Long, Discovery and Experts Under the Federal Rules of Civil Procedure, 38 F.R.D. 111, 119 (1965). See also Bartell, The Attomey-Client Privilege and Work Product Doctrine, in REsource Materials: Civil Practice and Immgation in Federal and State Courts 445, 557 (3d ed. 1985) (describing the confused state of the law prior to the 1970 amendment).

66. See supra note 31 and accompanying text.

67. See generally Annotation, Abuse of Process Action Based on Misuse of Discovery or Deposition Procedures After Commencement of Civil Action Without Seizure of Person or Property, 33 A.L.R. 4th 650, 651-54 (1984) (collecting state court decisions on abuse of process actions based on misuse of discovery or deposition procedures). For the argument that tort actions should not be used to control litigation abuse because they are too costly and time-consuming, see Underwood, Curbing Litigation Abuses: Judicial Control of Adversary Ethics-The Model Rules of Professional Conduct and Proposed Amendments to the Rulcs of Civil Procedure, S6 ST. JoHN's L. REv. 625, 629 
against a party who causes harm by using a legal process to accoinplish a purpose for which that process was not designed.68 In order to sustain a cause of action, the plaintiff must show that the defendant made an improper or perverted use of the process with an ulterior motive or purpose. 69

The plaintiff must overcome substantial obstacles. Given the liberality of modern discovery rales, it will often be difficult to establish improper motive. Additionally, the plaintiff must confront the view that "our adversarial system cannot function without zealous advocacy"70 and the practical desuetude of the tort. ${ }^{71}$ Some jurisdictions require a showing that the wrongful use of process resulted in the seizure of the plaintiff's property. ${ }^{72}$ Moreover, an action typically cannot exist until the case in which the alleged abuse occurred has been resolved. ${ }^{73}$ Given these hurdles, the possibility of relief on this basis offers scant comfort to the nonparty expert witness.

\section{B. Rule 11 Sanctions.}

Because Rule $11^{74}$ sanctions are directed at the source of abusive litigation practices, they represent a limited way to protect nonparty ex-

(1982). Underwood asserts that "the burden resulting from abuse of litigation can only be relieved by changes which foster stronger judicial control of adversarial ethics, and greater judicial involvement in the pretrial stages of litigation." Id.

68. RESTATEMENT (SECOND) OF TORTS § 682 (1977).

69. W. KeEton, D. Dobes, R. KeEton \& D. OWEN, Prosser \& KeEtoN ON the LAW OF ToRTs § 121, at 897-98 (5th ed. 1984) [hereinafter PROSSER \& KEETON]. However, "even a pure spite motive is not sufficient where process is issued only to accomplish the result for which it was created." Id. at 897.

70. Board of Educ. v. Farmingdale Classroom Teachers Ass'n, 38 N.Y.2d 397, 405, 343 N.E.2d 278, 283, 380 N.Y.S.2d 635, 643 (1975).

71. Id. at 400,343 N.E.2d at 280,380 N.Y.S.2d at 638 . Farmingdale contains a detailed discussion of the history of the tort. Id. at $400-03,343$ N.E.2d at 280-82, 380 N.Y.S.2d at 639.42 .

72. See Prosser \& KEETON, supra note $69, \S 121$, at 900 . An attomey is liable to a third party for abuse of process only if be maliciously participates or encourages and induces another to commit an act constituting an abuse. See Annotation, Civil Liabtlity of Attorney for Abuse of Process, 97 A.L.R.3d 688, 690-95 (1980).

73. See, eg., Steele v. Morris, 608 F. Supp. 274, 276 (S.D.W. Va. 1985).

74. The Rule states in part:

Every pleading, motion, and other paper of a party represented by an attorney shall be signed by at least one attorney of record .... A party who is not represented by an attorney shall sign his pleading, motion or other paper.... The signature of an attorney or party constitutes a certification by him that he has read the pleading, motion, or other paper; that to the best of his knowledge, information and belief formed after reasonable inquiry it is well grounded in fact and is warranted by existiug law or a good faith argnment for the extension, modification, or reversal of existing law, and that it is not interposed for any inproper purpose, such as to harass or to cause unnecessary delay or needless increase in the cost of hitigation.... If a pleading, motion, or other paper is signed in violation of this rule, the court, upon motion or upon its own initiative, shall impose upon the person who signed it, a represented party, or both, an appropriate sanction, which may include an order to pay to the other party or parties the amount of the reasonable 
perts. Unlike tort relief, Rule 11 sanctions are available without proof of malice. ${ }^{75}$

There is some precedent for applying sanctions to protect the interests of nonparties. In Westmoreland v. CBS, Inc., ${ }^{76}$ the United States Court of Appeals for the District of Columbia Circuit held that Rule 11 applied to nonlitigants subpoenaed for a deposition. ${ }^{77}$ The court imposed Rule 11 sanctions on a party for invoking an ungrounded citation for conteinpt against a nonparty, former CIA Director Richard Helms, ${ }^{78}$ after he refused to sit for a videotaped deposition even though both parties in the suit apparently had an "informal understanding" that Helms's deposition would be taped.79

Westmoreland thus indicates that nonparty witnesses have rights beyond those agreed to by the parties and may seek sanctions under sone circumstances. Nonetheless, Rule 11 may prove to be of little value to subpoenaed unretained experts. The text of Rule 11 does not mention misuse of subpoenas, which are signed by clerks rather than a party's counsel..$^{80}$ Broadening the sanction provision in Rule 11 to cover the misuse of subpoenas might be desirable. Whether rulemakers will change Rule 11 in hight of their recent overhaul of that rule remains an open question. ${ }^{81}$ In any event, the role of sanctions, particularly financial sanctions imposed against lawyers, remains controversial.82

expenses incurred because of the filing of the pleading motion, or other paper, including a reasonable attorney's fee.

FED. R. Civ. P. 11.

75. The revised rule has replaced a vague good faith standard with one requiring something closer to objective reasonableness. See FED. R. Crv. P. 11 advisory committee's note; see also Eastway Constr. Corp. v. City of New York, 762 F.2d 243, 253 (2d Cir. 1985) ("The] language of the new Rule 11 explicitly and unambiguously imposes an affirmative duty on each attorney to conduct a reasonable inquiry into the viability of a pleading before it is signed. Simply put, subjective good faith no longer provides the safe harbor it once did."). But see Gieringer v. Silverman, 731 F.2d 1272, 1281 (7th Cir. 1984) (requiring a showing of subjective bad faith before imposing sanctions).

76. 770 F.2d 1168 (D.C. Cir. 1985).

77. Id. at 1178. The significance of this ruling is that it extended Rule 11 sanctions to nonparty victims of discovery abuse. Id. at 1180 . The subpoenaed individual's expertise was not mentioned as a factor in the ruling, even though CBS apparently subpoenaed him because of his specialized knowledge as director of the CIA from 1966 to 1973. Id. at 1170-71. Moreover, the court did not rule that CBS could not depose the individual.

78. Id. at 1180.

79. Id. at 1171, 1180. According to the Federal Rules, "[t]he parties may stipulate in writing or the court may upon motion order that the testimony at a deposition be recorded by other than stenographic means." FED. R. Crv. P. 30 (b)(4). No such stipulation or order existed in this case, though Helms did agree to be deposed. Westmoreland, 770 F.2d at 1171.

80. See supra note 74 .

81. Rule 11 was last amended in 1983. See FED. R. Crv. P. 11 advisory committee's note.

82. Critics of broad application of sanctions argue that sanctions not only threaten to create satellite fitigation but also can inhibit lawyers' creativity and possibly chill settlements by destroying 


\section{AcComodation ThRough AMENDMENT OF the Federal Rules of CIVIL Procedure}

\section{A. The ABA's Proposal.}

In 1985, the ABA House of Delegates recommended that Rule 45 be amended to address the problems associated with subpoenas issued to unretained experts. ${ }^{83}$ The resolution made the following proposals:

1. That there be a limitation in the amount of expense in time and money required of a non-party witness complying with a subpoena and that any order of reimbursement of a non-party witness be prospective only.

2. That a non-party witness be afforded protection under Rules 26, 29 and 30 of the Federal Rules of Civil Procedure.

3. That the time limits for compliance with a subpoena by a non-party witness be at least the same as for a party.

4. That a party and non-party witness be given standing to object to the issuance of a subpoena.

5. That a non-party witness be given standing to object to the scope of discovery.

6. That documents in the control of a witness in one district be produced in response to a subpoena properly served upon a witness in another district.

7. That a non-party expert witness should not be required to give opimion testimony without compensation.

8. That sanctions upon a non-party withness [sic] under Rule 45 comport with the sanctions upon a party under Rule 37.

9. That the procedures of Rules 45 (b), (d) and (f) be changed as to the timing of a motion for the objection, after the failure to move under Rule 45(b) and as to the failure to object and/or appear or produce pursuant to Rule 45 (d)..$^{84}$

These principles only partially enhance protections for nonparty experts. Chiefly, the recommendations clarify rights already existing under the Federal Rules and encourage equitable treatment of parties and nonparties. In concrete terms, the proposed amendment corrects an inequity in the present rules by requiring that nonparties be given as much time to object to subpoenas as parties. The main value to subpoenaed nonparty experts, though, stems from the new standard for prospective compensation, the emphasis on limiting the burdens imposed on nonparties, and the recognition of the importance of opinion testimony.

In sum, these proposals require that special consideration be given to the particular concerns of nonparty experts. Still, the ABA recom-

a cooperative atmosphere. See, eg., Weiss, A Practioners' Commentary on the Actual Use of Amended Rule 11, 54 FORDHAM L. REv. 23, $23-24$ (1985).

83. See House of Delegates Formal Resolution, supra note 10.

84. Id. at 1-2. 
mendation does not go far enough. Most unretained experts will suffer harm unassociated with monetary considerations. For example, monetary compensation cannot cure the professional harm caused by the disclosure of certain kinds of information. Monetary compensation also is not necessarily an adequate solution when the information can be obtained from another source. The ABA proposal therefore only partially weighs the interest of the nonparty expert against the litigant's needs.

Deitchman v. E.R. Squibb \& Sons, Inc. ${ }^{85}$ is representative of cases suggesting that monetary compensation might not be nearly as important as other considerations to some unretained experts. ${ }^{86}$ E.R. Squibb \& Sons, a pharmaceutical company involved in a product hability suit, sought production of documents from a registry managed by Arthur $\mathrm{L}$. Herbst, chairman of the Department of Obstetrics and Gynecology at the University of Chicago. 87 In order to monitor clinical, pathological, and epidemiological aspects of a genital tract disease known as clear-cell adenocarcinoma, Herbst established a registry in 1972 to keep statistics on his research findings. ${ }^{88}$ The registry's goals included determining the incidence of the disease, discovering the relationship between prenatal treatment and other factors possibly infiuencing the occurrence of the disease, and determining the best means of treatment. ${ }^{89}$

Herbst was a nonparty to the lawsuit and the possibility of inadequate compensation for disclosure was not an issue because Squibb pledged to pay any expense that discovery required. ${ }^{90}$ Herbst feared, however, that disclosure would jeopardize his research by forcing the termination of a study begun in 1969 and later used as the basis for the registry. ${ }^{91}$ The court remanded the case for a reconsideration of the nnotion to quash the subpoena, noting that "[Squibb] appears to concede that the loss of confidentiality here will adversely affect the Registry and that, as the district judge stated, 'all society will be the poorer ... [and] a unique and vital resource for learning about the incidence, causes and treatment of adenocarcinoma will be lost." ${ }^{\prime 92}$

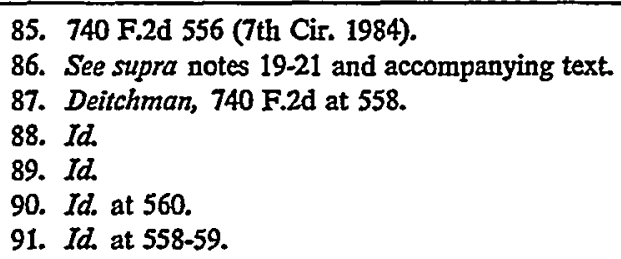

86. See supra notes 19-21 and accompanying text.

87. Deitchman, 740 F.2d at 558.

88. Id.

89. Id.

90. Id. at 560 .

91. Id. at 558-59.

92. Id. at 560 . Both the trial court and the court of appeals used balancing tests, arguably extending the requirements of the Federal Rules. The court of appeals balanced the drug company's need for information to present an adequate defense against the harm that compliance with the subpeona would cause to Herbst's registry. Id. at 559. The court held that "discovery should be no more intrusive than is necessary to avoid a miscarriage of justice. Anything not necessary must be viewed as covered by privilege." Id. at 565 . The trial court had quashed the subpoena on the 
The ABA's recommendation that Rule 45 be amended to guaranty experts prospective compensation for testimony, ${ }^{93}$ while itself insufficient, does suggest that the rules of procedure can guide courts in accomodating the conflicting interests of litigants and nonparty experts. By viewing the conflict essentially in financial terms, however, the proposal fails to ensure equitable consideration of the nonparty expert's unique position.

\section{B. The Privilege Proposal.}

One way to enhance protections for subpoenaed unretained experts would be for rulemakers to extend a privilege that would preclude the subpoenaing of opinion information or testimony. Although some state courts have adopted such a privilege, ${ }^{94}$ federal courts view such common law privileges skeptically ${ }^{95}$ and generally have been reluctant to expand the scope of privileges in recent years. ${ }^{96}$ Moreover, Congress has been unwilling to standardize certain common law privileges through the Federal Rules of Evidence, 97 and the advisory notes to the Federal Rules of Civil Procedure explicitly reject tlie notion that a privilege should attach to expertise. ${ }^{98}$

Even if such a privilege were feasible, it would be undesirable on policy grounds. Eliminating all opportunities to discover or introduce evidence that may be crucial to a lawsuit would be drastic in light of the "enormous range of 'expert' knowledge in inodern life."

\section{The Work-Product Standard.}

The scope of the qualified immunity provided by the work-product

grounds that the drug company's need for the information was speculative and the interest in defending itself was outweighed by the clanger that the disclosure of confidential information would jeopardize the research project and similar projects. Andrews v. Eli Iilly \& Co., 97 F.R.D. 502-03 (N.D. Ill. 1983), vacated, Deitchman v. E.R. Squibb \& Sons, Inc., 740 F.2d 556 (7th Cir. 1984).

93. See supra note 12 and accompanying text.

94. See, e.g., Commonwealth v. Vitello, 367 Mass. 224, 235, 327 N.E.2d 819, 827 (1975); People ex rel. Kraushaar Bros. \& Co. v. Thorpe, 296 N.Y. 223, 225, 72 N.E.2d 165, 165.66 (1947).

95. See note 45 and accompanying text.

96. See S. Saltzburg \& K. Redden, Federal Rules of Evidence Manual: A CoMPLETE Guide to THE FEDERAL Rules of Evidence 347 (4th ed. 1986).

97. In 1971, Congress rejected a recommendation to codify certain privileges under federal law. Id. at 331.

98. See FED. R. Crv. P. 26(b)(4) advisory committee's note.

99. Kaufman v. Edelstein, 539 F.2d 811, 820 (2d Cir. 1976). As Judge Friendly pointed out, "[t]o clothe all such expert testimony with privilege solely on the basis that the expert 'owns' his knowledge . . . would be to seal off ton much evidence important to the just determination of disputes." Id. at 821 . 
doctrine has expanded steadily.100 As formulated in Hickman v. Taylor, ${ }^{101}$ the doctrine provides a qualified immunity from discovery for any notes, working papers, memoranda, or similar materials prepared by an attorney in anticipation of litigation. ${ }^{102}$ It is designed to give an attorney freedom to investigate all aspects of a case without fear of having to turn over the material to opposing counsel. ${ }^{103}$ Such material, however, does not receive absolute protection. As one commentator notes:

Information that is collected in anticipation of litigation or trial is protected froin discovery, but that protection may yield to a showing of need on the part of the requesting party. Mental impressions of the attorney enjoy the highest level of protection under the work-product doctrine, but ... . even they may be revealed, at least in part, upon a sufficient showing. Thus, the application of the work-product rule often requires a balancing of the competing needs of the parties, as well as an inquiry into whether the material involved properly falls within the concerns that originally produced this discovery exception. ${ }^{104}$

A party seeking discovery inust demonstrate two things when the opposing side invokes the work-product doctrine. First, the party must show a substantial need for the material. ${ }^{105}$ Second, the party must show an imability to obtain the information elsewhere without undue hardship. ${ }^{106}$ Determining whether to allow discovery of information protected by the work-product doctrime thus depends largely on the availability of the material sought. 107

The standard proposed here is modeled after this doctrine. As applied to the unretained expert, the proposed standard would require the litigant to show a substantial need for the material and an inability to obtain the material or testimony elsewhere without undue hardship. In addition, in accord with the ABA recommendation, the subpoenaing party would be required to provide the nonparty with reasonable compensation on a prospective basis.

A court should conclude that the subpoenaed information is not available elsewhere if the subpoenaing party shows that it las exhausted all reasonable efforts to obtain it. This showing would require an affirma-

100. Under the work-product doctrine, material prepared by one party or for one party's representative is protected from discovery, unless the party seeking it can show a substantial need for the information and is unable to obtain it elsewhere without undue hardship. FED. R. CIV. P. 26(b)(3). For a discussion of the development of the doctrine, see Cohn, The Work-Product Doctrine: Protection, Not Privilege, 71 GEo. L.J. 917, 943 (1983).

101. 329 U.S. 495 (1947).

102. See J. Friedenthal, M. Kane \& A. Mitier, CiviL Procedure § 7.5, at 386-87 (1985).

103. Id.

104. Id. at 387.

105. FED. R. CIv. P. 26(b)(3).

106. Id.

107. See C. WRIGHT, supra note $30, \S 82$, at 556 . 
tive act on the part of the subpoenaing party that may vary depending on the circumstances of the litigation. The party might, for example, be required to seek comparable information from other experts. In other cases, a court might require the party to attempt to duplicate the research with his own resources.

Of course, this proposal will not solve every problem. Like any balancing standard, it cannot be applied mechanically. But the limited flexibility of the proposed rule is also one of its strengths. Within clear limits, designed to enhance fairness and consistency in the subpoenaing process, judges could weigh the relative burdens imposed on litigants and nonparties. ${ }^{108}$ Although the relevant considerations will vary from case to case, the proposed standard would limit judicial discretion and narrow the wide discrepancies that result from the application of present standards.

\section{CONCLUSION}

The $A B A$ and a number of judges recognize that nonparty experts subpoenaed to provide infolmation or testimony based on their expertise should be accorded protection from unfair appropriation of their special knowledge. No clear standard to ensure consideration of the interests of experts coinpelled to provicle information has emerged, however. Moreover, there is little chance that courts will develop a consistent, equitable standard under the current versions of Rules 45 and 26.

The ABA has recognized the problem and lias proposed that Rule 45 be amended. This note has argued that the ABA proposal would do little to resolve the problens. Accordingly, the note proposes that Rule 45 be amended to provide specific protection for nonparty experts comparable to that available to attorneys under the work-product doctrine. The amended rule would clarify the standards applicable to subpoenaing nonparty experts and curtail the confusion and inconsistent treatment of nonparty experts. Moreover, it would be in accord with the emphasis on fairness mandated by the Federal Rules and with the goal of encouraging liberal access to relevant information.

Mark Labaton

108. In addition, other societal interests may be considered. For example, Judge Edelstein based his decision to uphold subpeonas to two nonparty computer experts in one case in part on the importance that the case had for the nation. See U1nited States v. International Business Machs. Corp., 406 F. Supp. 175, 177 (S.D.N.Y. 1975) (describing "major government antitrust" case as one which "greatly affects the commonweal"), appeal dismissed sub. nom. Kaufman v. Edelstein, 539 F.2d 811 (2d Cir 1976). 